\title{
EVALUATION STUDY MANAGEMENT OF SOLID MEDICAL WASTE AT DR. H. SLAMET MARTODIRDJO HOSPITAL PAMEKASAN
}

\author{
Nazilatul Fadhoilah, Waluyo jati, Darjati
}

\begin{abstract}
Results of the conducted initial survey found that there were some issues where medical waste containers were not in place and incineration of solid medical waste was not done within the usual 5 day period. This study was aimed at evaluating the management of solid medical waste at Dr. H. Slamet Martodirdjo hospital in Pamekasan.

This study was designed as a descriptive study, conducted in February - June of 2013. Data were analyzed descriptively and to be discussed with reference to the KepMenKes No.1204 /Menkes/SK/X/2004 on Hospital Environmental Health Requirements.

Results of this study indicated that solid medical waste at hospital of Dr. H. Slamet Martodirdjo Pamekasan was generated from health care activities performed in the emergency room, ICU and other units in the form of infectious materials and sharps. Largest amount of solid medical waste was produced usually on Monday at $50 \mathrm{~kg}$, while the smallest amount generated in any other day of the week wasapproximately $12 \mathrm{~kg}$. Evaluation on the solid medical waste management resulted in a score of $75.64 \%$ and considered as a non-compliance. The smallest percentage achieved in the assessment was $28.6 \%$ obtained by janitorial service and the largest percentage was from the transportion as much as $90 \%$.

The study concluded that the management of solid medical waste in Pamekasan hospitals is not complying to the designated standards. The study suggested that Dr.H.Slamet Martodirdjo Pamekasan hospital should make immediate corrections pertaining to medical solid waste management and improvement of the janitorial service, the system, and a schedule that is in compliance to the KepMenKes No.1204/Menkes/SK/X/2004 on Hospital Environmental Health Requirements.
\end{abstract}

Keywords : Solid medical waste, Hospital

\section{PENDAHULUAN \\ Latar belakang}

Dewasa ini limbah padat merupakan masalah yang cukup serius, terutama di kota - kota besar. Sehingga banyak upaya yang dilakukan oleh pemerintah daerah, swasta maupun secara swadaya oleh masyarakat untuk menanggulanginya, dengan cara mengurangi, mendaur ulang maupun memusnahkannya. Namun semua itu hanya bisa dilakukan bagi sampah yang dihasilkan oleh rumah tangga saja. Lain halnya dengan limbah padat yang dihasilkan dari upaya medis seperti Puskesmas, Poliklinik, dan Rumah Sakit. Limbah padat rumah sakit digolongkan menjadi dua yaitu limbah medis padat dan limbah non medis padat. Seperti yang kita ketahui rumah sakit merupakan penghasil limbah medis padat terbesar. Berbagai jenis limbah padat yang dihasilkan di rumah sakit dan unit - unit pelayanan medis bisa membahayakan dan menimbulkan gangguan kesehatan bagi pengunjung dan terutama petugas yang menangani limbah medis padat tersebut serta masyarakat sekitar rumah sakit. Pengelolaan limbah medis padat rumah sakit sangat dibutuhkan bagi kenyamanan dan kebersihan rumah sakit, karena dapat memutuskan mata rantai penyebaran penyakit menular, terutama infeksi nosokomial.

Rumah Sakit Umum Daerah Dr. H. Slamet Martodirdjo Pamekasan merupakan rumah sakit pemerintah bertipe $B$ dengan diketahui BOR (Bed Ocoupancy Rate) $84,73 \%$ dan jumlah limbah medis padat rata - rata per hari sebesar $34.75 \mathrm{Kg}$. Dari survey pendahuluan pada bulan maret ditemukan beberapa masalah yaitu pada setiap ruangan yang menghasilkan limbah padat masih terdapat limbah medis padat yang tercampur dengan limbah non medis padat, masih terdapat kantong plastik untuk limbah infeksius yang tidak sesuai dengan kategori warna kantong plastik serta ada beberapa wadah limbah medis yang tidak disertai label, pembakaran 
limbah medis padat tidak dilakukan setiap hari melainkan 5 hari sekali kondisi ini tidak sesuai dengan peraturan pada KepMenKes 1204 tahun 2004.

Dari latar belakang diatas maka penulis tertarik untuk melakukan penelitian dengan judul "Studi Evaluasi Pengelolaan Limbah Medis Padat Di Rsud Dr. H. Slamet Martodirdjo Pamekasan Tahun 2013". Yang bertujuan Mengevaluasi pengelolaan limbah medis padat di RSUD Dr. H. Slamet Martodirdjo Pamekasan.

\section{METODE PENELITIAN}

Berdasarkan metodenya termasuk penelitian deskriptif. Metode penelitian deskriptif adalah suatu metode penelitian yang dilakukan dengan tujuan utama untuk membuat gambaran atau deskripsi tentang suatu keadaan secara objektif.

Lokasi dalam penelitian ini adalah RSUD Dr. $\mathrm{H}$. Slamet Martodirdjo Pamekasan dan dilaksanakan bulan Februari - Juni Tahun 2013. Untuk objek penelitian ini adalah pengelolaan limbah medis padat di Rumah Sakit Umum Daerah Dr. H. Slamet Martodirdjo Pamekasan.

Variabel penelitian ini meliputi Tahap penimbulan dan jumlah penimbulan limbah medis padat, Penyimpanan limbah medis padat, Pengumpulan limbah medis padat, Pengangkutan limbah medis padat, Tahap pengolahan akhir, Tahap pengelolaan limbah medis padat, Pengorganisasian, Ketenagaan, Perlengkapan dan peralatan, Biaya dan anggaran serta Peraturan dan landasan.

Prosedur pengumpulan data terdiri dari data primer yaitu melalui kegiatan observasi, wawancara, dan pengukuran. Sedangkan data sekunder yaitu diperoleh dari RSUD Dr. H. Slamet Martodirdjo Pamekasan.

Data yang terkumpul akan disajikan dalam bentuk tabulasi dan dianalisis secara deskriptif, sehingga diperoleh gambaran tentang sistem pengelolaan limbah medis padat di RSUD Dr. H. Slamet Martodirdjo Pamekasan.

\section{HASIL PENELITIAN DAN PEMBAHASAN}

A. Tahap Penimbulan dan Jumlah Penimbulan Limbah Medis Padat

Pengukuran limbah medis padat dilakukan selama tujuh hari dengan berat yang berbeda, hal tersebut di pengaruhi oleh aktivitas setiap harinya berbeda. Hasil pengukuran yang sudah dilakukan didapatkan jumlah terbesar yaitu pada hari senin sebesar $50 \mathrm{Kg}$, sedangkan jumlah terkecil didapatkan pada hari minggu yaitu sebesar $12 \mathrm{Kg}$. Hal ini disebabkan banyaknya aktivitas yang dilakukan dari pada hari - hari yang lainnya. Jumlah limbah medis padat terbesar pada ruangan bedah sentral sebesar $58 \mathrm{Kg}$ dan terkecil pada ruangan Bank Darah sebesar 2,5 Kg. Ruangan bedah sentral penghasil limbah medis padat terbesar karena penggunaan bahan - bahan medis yang lebih banyak dari pada ruangan lainnya.

Tahap penimbulan di RSUD Dr. H. Slamet Martodirdjo Pamekasan memperoleh skor sebesar 65 yang berarti $65 \%$ dan tidak memenuhi syarat yaitu nilai yang didapatkan minimal lebih dari $80 \%$. Nilai tersebut diperoleh karena bahan dan alat yang tersedia memang bersifat disposable. Semua petugas di rumah sakit belum dapat melakukan reduksi bahan, melainkan tetap menggunakan bahan - bahan sekali pakai.

Hal tersebut belum sesuai dengan persyaratan pengelolaan limbah medis padat pada KepMenKes No.1204/Menkes/SK/X/2004. Dimana setiap rumah sakit seharusnya melakukan reduksi limbah padat dimulai dari sumber. Dengan tidak melakukan reduksi dapat menyebabkan penimbulan sampah medis yang terlalu melimpah.

\section{B. Tahap Penyimpanan Limbah Medis Padat}

Pada tahap ini RSUD Dr. H. Slamet Martodirdjo Pamekasan menyediakan sarana tempat penyimpanan sementara atau tempat sampah medis. Berdasarkan hasil penilaian yang telah dilakukan dari 56 buah tempat sampah medis, untuk tempat sampah infeksius terdapat 9 buah tempat sampah yang memenuhi syarat dan 23 buah tempat sampah yang tidak memenuhi syarat. Sedangkan untuk tempat sampah benda tajam terdapat 7 buah tempat sampah yang memenuhi syarat dan 17 buah tempat sampah yang tidak memenuhi syarat.

Dari formulir penilaian pada penyimpanan setempat di RSUD Dr. $H$. Slamet Martodirdjo Pamekasan, terhadap masing masing tempat sampah terdapat 16 buah tempat sampah yang memenuhi syarat dengan prosentase $28,5 \%$ dan terdapat 40 buah tempat sampah yang tidak memenuhi syarat dengan prosentase $71,5 \%$. Skor 
secara keseluruhan sebesar 164,28 yang berarti $82,14 \%$ dan memenuhi syarat yaitu nilai yang didapatkan lebih dari $80 \%$. Tersedia tempat sampah medis di setiap ruangan, namun masih terdapat tempat sampah medis menggunakan kantong plastik yang belum disesuaikan dengan pedoman yang ada. Tempat sampah, secara umum telah tertutup, kedap air dan tahan karat, namun masih terdapat tempat sampah medis yang belum dilengkapi dengan warna dan label sesuai yang ditetapkan. Pada wadah benda tajam hanya terdapat beberapa ruangan yang menggunakan safety box yaitu pada ruangan UGD, ICU, Zal B, Zal D, bank darah dan poli gigi dan mulut.sedangakan ruangan yang lain tidak menggunakan wadah yang berupa safety box yang sesuai dengan pedoman, namun menggunakan tempat sampah yang terbuat dari bahan plastik dan kantong plastik yang tidak sesuai.

Hasil pengamatan tersebut belum sesuai dengan persyaratan yaitu penyimpanan tempat sampah medis yang tercantum dalam KepMenKes No. 1204 / Menkes / SK / X / 2004 yang mana pewadahan sampah medis padat harus memenuhi persyaratan dengan penggunaan wadah dan label seperti tabel. Kondisi tempat sampah yang belum dilapisi dengan kantong plastik sesuai warna serta label yang telah ditentukan bisa menyebabkan terjadinya kesalahan penanganan pada tahap pengumpulan hingga pengolahan akhir, dimana yang seharusnya mendapatkan perlakuan khusus, tetapi mendapatkan perlakuan yang sama dengan sampah lainnya.

\section{Tahap Pengumpulan Limbah Medis Padat}

Pada tahap pengumpulan, RSUD Dr. H. Slamet Martodirdjo Pamekasan memperoleh skor sebesar 78,56 yang berarti $78,56 \%$ dan tidak memenuhi syarat yaitu nilai yang didapatkan kurang dari $80 \%$. Pada tahap pengumpulan, setiap ruangan tersedia tempat sampah, namun masih terdapat tempat sampah yang belum memenuhi syarat yaitu wadah, kantong plastik dan label sampah medis yang tidak sesuai dengan persyaratan. Kondisi tempat sampah dan kantong plastik yang belum sesuai warna serta label yang telah ditentukan bisa menyebabkan terjadinya kesalahan penanganan pada tahap pengumpulan hingga pengolahan akhir, dimana yang seharusnya mendapatkan perlakuan khusus, tetapi mendapatkan perlakuan yang sama dengan sampah lainnya. Kondisi tersebut belum sesuai dengan persayaratan yang tercantum dalam KepMenKes No. 1204 / Menkes / SK / X / 2004 yaitu tempat sampah medis seharusnya wadah dan plastik yang digunakan sesuai dengan warna dan label yang sudah ditentukan.

\section{Tahap Pengangkutan Limbah Medis Padat}

Pada tahap pengangkutan, RSUD Dr. H. Slamet Martodirdjo Pamekasan memperoleh skor sebesar 180 yang berarti $90 \%$ dan memenuhi syarat yaitu nilai yang didapatkan lebih dari $80 \%$. Pada tahap pengangkutan ini, hampir seluruh persyaratan terpenuhi, kecuali pada lokasi TPS kurang bersih karena banyaknya tumpukan hasil pembakaran limbah medis padat yang tidak tertata rapi serta tidak di lengkapi fasilitas pencucian.

Hal tersebut belum sesuai dengan persayaratan yang tercantum dalam KepMenKes No. 1204 / Menkes / SK / X / 2004 yaitu kondisi TPS dalam keadaan bersih dan terdapat fasilitas pencucian. Kondisi TPS yang kurang bersih bisa menyebabkan tempat bersarangnya vektor penyakit atau binatang pengganggu lainnya. Belum tersedianya fasilitas pencucian bisa menghambat petugas pengumpul limbah medis padat membersihkan diri setelah melakukan kegiatannya.

\section{E. Tahap Pengolahan Akhir Limbah Medis Padat}

Pada tahap pengolahan akhir, RSUD Dr. H. Slamet Martodirdjo Pamekasan memperoleh skor sebesar 240 yang berarti $80 \%$ dan memenuhi syarat yaitu nilai yang didapatkan minimal lebih dari $80 \%$. Pada tahap ini hampir seluruh persyaratan terpenuhi. Kecuali pada hasil pembakaran limbah medis padat belum dilakukan penanganan khusus.

Hal tersebut belum sesuai dengan persyaratan yang tercantum dalam KepMenKes No. 1204 / Menkes / SK / X / 2004 yaitu dilakukan penanganan khusus pada hasil pembakaran limbah medis padat. Hasil pembakaran limbah medis padat di RSUD Pamekasan hanya dibungkus dengan karung beras yang kararteristik karung 
beras mudah sobek karena terbuat dari plastik dan bisa mengakibatkan hasil pembakaran tersebut tercecer. Apabila tidak segera dilakukan penanganan khusus maka akan mengakibatkan penumpukan limbah medis padat.

\section{F. Tahap Pengelolaan Limbah Medis Padat}

Tabel. 1

\section{DATA HASIL PENILAIAN PENGELOLAAN LIMBAH MEDIS PADAT DI RSUD Dr. H. SLAMET MARTODIRDJO PAMEKASAN}

\begin{tabular}{clcccc}
\hline No. & Tahap Pengelolaan & Bobot & $\begin{array}{c}\text { Skor } \\
\text { Maks }\end{array}$ & $\begin{array}{c}\text { Skor } \\
\text { Obs }\end{array}$ & $\begin{array}{c}\text { Prosentase } \\
\text { \% }\end{array}$ \\
\hline 1. & Tahap Penimbulan & 1 & 100 & 65 & 65 \\
\hline 2. & Tahap Penyimpanan & 2 & 200 & 164,28 & 82,14 \\
\hline 3. & Tahap Pengumpulan & 1 & 100 & 78,56 & 78,56 \\
\hline 4. & Tahap Pengangkutan & 2 & 200 & 180 & 90 \\
\hline 5. & Tahap Pengolahan Akhir & 3 & 300 & 240 & 80 \\
\hline 6. & Petugas Kebersihan & 1 & 100 & 28,6 & 28,6 \\
\hline \multicolumn{7}{r}{ TOTAL } & $\mathbf{1 0}$ & $\mathbf{1 0 0 0}$ & $\mathbf{7 5 6 , 4 4}$ & $\mathbf{7 5 , 6 4}$ \\
\hline
\end{tabular}

Pada tahap pengelolaan limbah medis padat, RSUD Dr. H. Slamet Martodirdjo Pamekasan memperoleh skor sebesar 756,44 yang berarti $75,64 \%$ dan tidak memenuhi syarat yaitu nilai yang didapatkan kurang dari $80 \%$. Prosentase terkecil di peroleh pada petugas kebersihan yaitu sebesar $28,6 \%$ dan prosentase terbesar pada tahap pengangkutan sebesar $90 \%$.

Hal tersebut belum memenuhi persyaratan yang tercantum pada KepMenKes No.1204 / Menkes / SK / X / 2004 dimana yang telah dijelaskan pada tahap penimbulan pengolahan akhir masih terdapat persyaratan - persyaratan yang belum terpenuhi.

\section{G. Aspek Penunjang Pengelolaan Limbah Medis Padat}

1. Pengorganisasian

Sanitasi di RSUD Dr. H. Slamet Martodirdjo Pamekasan ditangani oleh bagian IPL - RS (Instalasi Penyehatan Lingkungan Rumah Sakit), dimana pada bagian ini langsung bertanggung jawab kepada Direktur Rumah Sakit. Namun di RSUD Pamekasan tidak terdapat Struktur Organisasi secara tertulis. Sehingga menjadi faktor penghambat terhadap tugas yang akan dilakukan oleh setiap petugas ataupun pada organisasi pengelola limbah medis padat.

\section{Ketenagaan}

Di RSUD Dr. H. Slamet Martodirdjo Pamekasan terdapat 4 orang pengawas yang mengawasi terhadap pengelolaan limbah medis padat. Sedangkan petugas limbah medis padat terdapat 33 orang. Tenaga pengumpul limbah medis padat tersebut belum menggunakan APD (Alat Pelindung Diri) dengan lengkap, mereka hanya menggunakan masker dan sarung tangan pada saat melakukan kegiatan pengelolaan limbah medis padat. Hal tersebut kurang sadarnya petugas kebersihan terhadap pentingnya menggunakan APD (Alat Pelindung Diri).

\section{Perlengkapan dan Peralatan}

Perlengkapan dan peralatan yang ada di RSUD Dr. H. Slamet Martodirdjo Pamekasan untuk mendukung pengelolaan limbah medis padat sudah terpenuhi. Dimana setiap ruangan penghasil sampah sudah terdapat bak sampah dan dilakukan perbaikan pada alat kebersihan yang rusak.

\section{Biaya dan Anggaran}

Pembiayaan yang digunakan oleh RSUD Dr. H. Slamet Martodirdjo Pamekasan yaitu berasal dari APBD (Anggaran Pendapatan Belanja Daerah) yang mana untuk anggaran pembiayaan pengelolaan sampah bergabung dengan anggaran jasa dan kebersihan kantor. Sedangkan untuk upah petugas pelaksana pengelola limbah padat, anggaran biaya menjadi tanggung jawab pihak RSUD Pamekasan.

\section{Peraturan atau landasan Kerja}

RSUD Dr. H. Slamet Martodirdjo Pamekasan memiliki peraturan atau landasan pengelolaan limbah medis padat yang 
diadopsi dari pedoman yang tertulis di KepMenKes RI No. 1204 / Menkes / SK / X / 2004 tentang persyaratan kesehatan lingkungan rumah sakit. Namun pada peraturan tersebut masih terdapat yang belum dilaksanakan, SOP pembakaran limbah medis padat, wadah limbah medis padat, dan masih ada petugas yang belum menggunakan APD (Alat Pelindung Diri).

\section{KESIMPULAN DAN SARAN}

\section{A. Kesimpulan}

Maka penulis dapat mengambil kesimpulan sebagai berikut : 1) Jumlah (berat) timbulan limbah medis padat selama 1 minggu, paling besar adalah hari senin. Hari senin sebesar $50 \mathrm{Kg}$ dan pada ruangan bedah sentral penghasil jumlah limbah medis padat terbesar dengan jumlah sebesar $58 \mathrm{Kg}$. Pada tahap penimbulan tidak memenuhi syarat dengan prosentase $65 \%$ karena bahan dan alat yang tersedia masih bersifat disposable. 2) Pada tahap penyimpanan setempat, limbah medis padat memenuhi syarat, dengan prosentase $82,14 \%$, masih ada tempat sampah medis yang tidak memenuhi syarat. Terdapat 16 buah tempat sampah yang memenuhi syarat dan 40 buah tempat sampah yang tidak memenuhi syarat. 3) Pada tahap pengumpulan, limbah medis padat tidak memenuhi syarat, dengan prosentase $78,56 \%$, tetapi pada tempat sampah medis belum sesuai dengan pedoman yang ada. 4) Pada tahap pengangkutan, limbah medis padat memenuhi syarat, dengan prosentase $90 \%$, tetapi pada lokasi TPS, kurang bersih dan tidak dilengkapi fasilitas pencucian. 5) Pada tahap pengolahan akhir, limbah medis padat memenuhi syarat, dengan prosentase $80 \%$, tetapi pada abu hasil pembakaran limbah medis padat belum dilakukan penanganan khusus. 6) Aspek penunjang pengelolaan limbah medis padat a) Pengorganisasian : Tidak ada Struktur Organisasi secara tertulis pada bagian IPL RS (Instalasi Penyehatan Lingkungan Rumah Sakit). b)Ketenagaan : Petugas pengumpul limbah medis padat belum menggunakan APD (Alat Pelindung Diri) dengan lengkap pada saat melakukan kegiatan. c) Perlengkapan dan Peralatan di RSUD Pamekasan untuk mendukung pengelolaan limbah medis padat, sudah terpenuhi. d) Biaya dan Anggaran : Pembiayaan untuk pengelolaan sampah berasal dari APBD (Anggaran Pendapatan Belanja Daerah). e) Peraturan dan
Landasan : Peraturan atau pengelolaan limbah medis padat didasarkan KepMenKes RI No. 1204 / Menkes / SK / X / 2004 tentang persyaratan kesehatan lingkungan rumah sakit, namun ada beberapa item yang belum dilaksanakan dengan sempurna yaitu SOP pembakaran limbah medis padat, wadah limbah medis padat dan masih ada petugas yang belum menngunakan APD (Alat Pelindung Diri).

\section{B. Saran}

Sarannya sebagai berikut a) Sebaiknya pihak RSUD Dr. H. Slamet Martodirdjo Pamekasan untuk meminimasi timbulan sampah dapat menggunakan alat yang dapat digunakan ulang misalnya jarum suntik yang dapat digunakan lebih dari sekali dengan melalui proses sterilisasi. b) Sebaiknya pihak RSUD Dr. H. Slamet Martodirdjo Pamekasan melakukan perubahan terutama dilakukannya pembenahan tempat sampah medis dengan membedakan kantong dan label sesuai warna yang telah ditetapkan dalam KepMenKes No.1204/Menkes/SK/X/2004. c) Sebaiknya pihak RSUD Dr. H. Slamet Martodirdjo Pamekasan pada lokasi TPS diberikan sarana air bersih untuk fasilitas pencucian dan memberikan tempat khusus berupa drum tertutup yang karakteristik dari bahan tersebut tidak mudah sobek dan terhadap hasil pembakaran limbah medis padat agar terlihat bersih dan rapi. d) Sebaiknya pihak RSUD Dr. H. Slamet Martodirdjo Pamekasan melakukan penanganan khusus terhadap hasil sisa pembakaran, dengan dilakukan kerjasama dengan pihak ketiga yang terkait, dinas kebersihan dan petamanan. e) Sebaiknya struktur organisasi di buat secara tertulis pada bagian IPL - RS. f) Sebaiknya setiap petugas pengumpul limbah medis padat diwajibkan memakai APD (Alat Pelindung Diri) yang lengkap, dan perlu diberikan sanksi berupa teguran secara tertulis dan tindakan kepada petugas pengumpul limbah medis padat yang tidak menggunakan APD (Alat Pelindung Diri), serta dilakukan penyuluhan tentang pentingnya menggunakan APD (Alat Pelindung Diri).

\section{DAFTAR PUSTAKA}

Azwar, Azrul, 1998. Pengantar IImu Kesehatan Lingkungan. Jakarta : PT Mutiara Sumber Widya. 
Afria. 2010. Kajian Pengelolaan Limbah Medis Padat Pada Puskesmas Rawat Inap Di Wilayah Kerja Dinas Kesehatan Kota Surabaya Tahun 2010. Surabaya: Kesehatan Lingkungan.

Depkes RI, 2002. Pedoman Sanitasi Rumah Sakit di Indonesia. lakarta: Direktorat Jendral PPM \& PLP.

Depkes RI, 1996. Pedoman Teknis Pengelolaan Limbah Klinis dan Desinfeksi \& Sterilisasi di Rumah Sakit. Jakarta: Direktorat Jendral PPM \& PLP.

Jais, Ahmad, 2009. Pengelolaan Limbah Medis Rumah Sakit.//http:everybody needs fantasy// di akses tanggal 20 februari 2013 Pukul 15.20 WIB

Keputusan Menteri Kesehatan Republik Indonesia Nomor 1204 / Menkes / SK / X / 2004 Tentang Persyaratan Kesehatan Lingkungan Rumah Sakit.
Munif, 2008. Solusi Alternatif Penanganan Sampah. (http://www. maxpelltechnology.com/incineratorm edis.php) di akses tanggal 12 februari 2013 Pukul 16.20 WIB

Notoatmojo, Soekidjo, 2010. Metodologi Penelitian Kesehatan. Jakarta : PT Rineka Cipta.

Santoso, Urip, ,2012. Pengelolaan Limbah Rumah Sakit (http://kesehatan.net/pengelolaanlimbah-rumah-sakit/) di akses tanggal 1 maret 2013 Pukul 19.45WIB

Sanropie, Djasio dkk, 1989. Komponen Sanitasi Rumah Sakit Untuk Institusi Pendidikan Tenaga Sanitasi. Jakarta : Depkes RI.

Sarudji, Didik, 1985. Pengelolaan Sampah. Surabaya : APK.

Undang - Undang Republik Indonesia Nomor 18 Tahun 2008 Tentang Pengelolaan Sampah. 